\title{
未破裂脳動脈瘤の自然歴
}

高橋 淳 ${ }^{1)}$, 片岡 大治 ${ }^{1)}$, 佐藤 徹 ${ }^{1)}$, 森 久恵 ${ }^{1)}$

国立循環器病研究センター脳神経外科

\section{Natural History of Unruptured Intracranial Aneurysms}

\author{
Jun C. Takahashi, M.D., Ph.D. ${ }^{1)}$, Hiroharu Kataoka, M.D., Ph.D. ${ }^{1)}$, Tetsu Satow, M.D., Ph.D. ${ }^{1)}$, \\ and Hisae Mori, M.D. ${ }^{1)}$ \\ Department of Neurosurgery, National Cerebral and Cardiovascular Center
}

Since 2003, five prospective studies on unruptured intracranial aneurysms have demonstrated their natural course (i.e. annual rupture rates) in detail. Recently, in addition, several meta-analyses, pooled analyses, risk scoring studies have been reported. Because there are many quotations of clinical data between these kinds of analyses, one must understand precisely where the pooled data come from. The risk factors for aneurysmal rupture proposed in the five prospective studies differ greatly from each other, and one must also understand these differences as well.

UCAS, which is the prospective multicenter study across Japan published in 2012, has marked the milestone in the field of intracranial aneurysm research especially in the Japanese cohort. To make reasonable judgements in daily clinical activities, physicians should read the UCAS manuscript and its supplementary appendix carefully and understand the true natural course of unruptured intracranial aneurysms in Japan.

(Received December 5, 2017 ; accepted December 20, 2017)

Key words : unruptured intracranial aneurysms, natural history, annual rupture rate, UCAS Japan, risk scoring

Jpn J Neurosurg（Tokyo）27:184-191, 2018

\section{はじめに}

未破裂脳動脈瘤の自然歴は患者と脳神経外科医にとつ て最大の関心事であり，これまで多くの研究が重ねられ てきた。前世紀の研究の多くは後方視的であったが, 2000 年以降の $5 つ の$ 前方視的研究によって新知見が得ら れ，近年はこれらのデー夕に基づく risk scoring system が提唱されている。本稿ではこれまでの未破裂脳動脈瘤 研究の歴史を整理するとともに, 問題点を提示したい.

\section{自然歴に関する後方視的研究}

未破裂脳動脈瘤の自然歴に関する論文には, メタアナ リシスや先行する前方視的研究群の統合解析 (pooled analysis）など, デー夕の引用・連結が多くみられる。研 究の系譜を俯瞰・理解するために, 未破裂脳動脈瘤研究

の「系統樹」(phylogenetic tree）を作製した（Fig. 1). 破裂率に関する後方視的研究を, 系統樹の左列に配置 した。これ以前にも 1966 年 Locksley（米国）の 32 例の 検討 ${ }^{8)}$ をばめ散発的な報告があるが，いずれも症例数

連絡先：高橋 淳, $\bar{T}$ 565-8565 吹田市藤白台 5-7-1 国立循環器病研究センター脳神経外科

Address reprint requests to : Jun C. Takahashi, M.D., Ph.D., Department of Neurosurgery, National Cerebral and Cardiovascular Center, 5-7-1 Fujishirodai, Suita-shi, Osaka 565-8565, Japan 


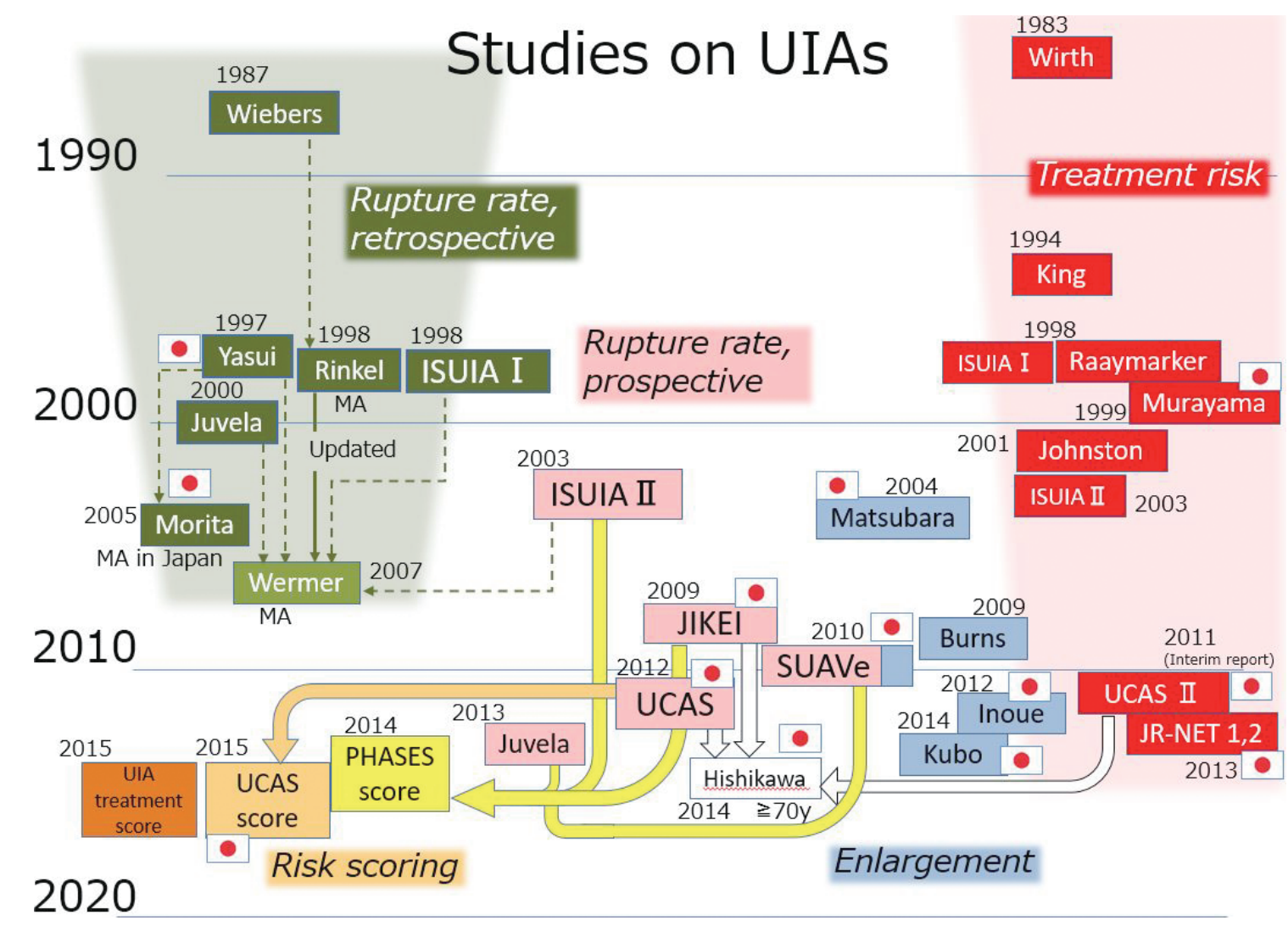

Fig. 1 Phylogenetic tree of the studies on unruptured intracranial aneurysms Japanese national flags indicate the studies of Japanese cohorts. UIAs : unruptured intracranial aneurysms, MA : metaanalysis

は少ない. 多数例検討の端緒は Wiebers（米国）らによ る 130 例報告（1987 年）で，平均 8.3 年の観察期間中に 15 例が破裂し, 破裂率は $1.4 \%$ /年と算出された ${ }^{18)}$ 。本邦 では 1997 年に Yasui らが，234 例の平均 6.3 年間の破裂 率を $2.3 \% /$ 年と算出した ${ }^{19)}$ 。これは後年明らかになる 「日本人の高い破裂率」を示唆している.

1998 年に発表された ISUIA（International Study of Unruptured Intracranial Aneurysms） I（北米・欧州）は, これまでの後方視的研究中, 最大の症例数 $(1,449$ 例) を 有する国際共同研究である ${ }^{4)}$. 1970 1991 年に未破裂脳 動脈瘤 1,449 人 1,937 動脈瘤が平均 8.3 年間観察された。 くも膜下出血（subarachnoid hemorrhage：SAH）歴のな い群 (group 1: 727 例) に抢ける破裂リスクは瘤径 $10 \mathrm{~mm}$ 未満で $0.05 \% /$ 年, $10 \mathrm{~mm}$ 以上で $1 \% /$ 年と, きわめて低 かった。SAH 歴のある群 (group 2: 722 例) では瘤径 10 $\mathrm{mm}$ 未満で $0.5 \% /$ 年と group 1 の 20 倍に上昇するものの, $10 \mathrm{~mm}$ 以上では group 1 同様の $1 \% /$ 年にとどまった (Table 1A)。本研究の結論は「SAH 歴のない患者の 10 $\mathrm{mm}$ 未満の脳動脈瘤はほとんど破裂せず，治療合併症リ スクとのトレードオフが成立しない」ということであり,
現実との乘離に関して大きな論争が起こった，後方視的 研究で不可避の症例選択バイアス, 動脈瘤部位分布の偏 り(group 1 の 40\%が後交通動脈分岐部以外の内頝動脈 瘤と海綿静脈洞部動脈瘤）などが指摘されたが，本研究 は特に欧米の臨床現場に大きな影響を及ぼした。

本邦における後方視的研究デー夕は, 2005年 Morita ら によるメタアナリシスにまとめられた ${ }^{9)}$.1992〜2003 年 の 13 研究 922 症例の解析で, 破裂例 104, 破裂率 2.7\%/ 年と算出し, 北米での ISUIA I よりも高リスクであるこ とを示した。(1)瘤の大きさ，(2)後方循環，(3)症候性病変 が有意なリスク因子であった。

\section{自然歴に関する前方視的研究}

前方視的研究を, 系統樹（Fig. 1）の中央列に配した.

\section{ISUIA II (北米, 欧州, 2003 年) ${ }^{5)}$}

脳動脈留に関する初の大規模前方視的研究であり, 4,060 患者が前向きに登録された。2,368 人が治療され， 未治療の 1,692 人 (group 1: 1,077, group 2:615) 2,686 
Table 1 Rupture rate proposed in the ISUIA I ${ }^{4)}$ and ISUIA II ${ }^{5)}$

A ISUIA I (Retrospective)

\begin{tabular}{c|c|c|c}
\hline & $<10 \mathrm{~mm}$ & $\geqq 10 \mathrm{~mm}$ & $(\geqq 25 \mathrm{~mm})$ \\
\hline Group 1 & $0.05 \% / \mathrm{y}$ & $1 \% / \mathrm{y}$ & $6 \%$ in the first year \\
Group 2 & $0.5 \% / \mathrm{y}$ & $1 \% / \mathrm{y}$ & \\
\hline
\end{tabular}

B ISUIA II (Prospective)

\begin{tabular}{l|cr|c|c|c}
\hline & \multicolumn{2}{|c|}{$<7 \mathrm{~mm}$} & $7 \sim 12 \mathrm{~mm}$ & $13 \sim 24 \mathrm{~mm}$ & $\geqq 25 \mathrm{~mm}$ \\
\hline Anterior & Group 1 & $0 \% / 5 \mathrm{y}$ & $2.6 \% / 5 \mathrm{y}$ & $14.5 \% / 5 \mathrm{y}$ & $40 \% / 5 \mathrm{y}$ \\
& Group 2 & $1.5 \% / 5 \mathrm{y}$ & & & \\
IC-PC/posterior & Group 1 & $2.5 \% / 5 \mathrm{y}$ & $14.5 \% / 5 \mathrm{y}$ & $18.4 \% / 5 \mathrm{y}$ & $50 \% / 5 \mathrm{y}$ \\
& Group 2 & $3.4 \% / 5 \mathrm{y}$ & & & \\
Cavernous & $0 \% / 5 \mathrm{y}$ & $0 \% / 5 \mathrm{y}$ & $3.0 \% / 5 \mathrm{y}$ & $6.4 \% / 5 \mathrm{y}$ \\
\hline
\end{tabular}

Group 1: History of SAH (-)

Group 2: History of SAH $(+)$

動脈瘤を平均 4.1 年間観察した（途中で 534 人が治療に 移行， 193 人が死亡， 4 人が脱落のためおのおの除外). 瘤の大きさ (4 段階) と部位 (前方循環, 後方循環, 海 綿静脈洞部）により観察期間中の破裂率を算出した (Table 1B)。な扮本研究では, 内頝動脈-後交通動脈分岐 部（internal carotid-posterior communicating artery：ICPC）動脈溜は後方循環に含まれる。

期間中， 51 人（3\%）に破裂イベントが生じた。前方 循環病変については, SAH 歴のない $7 \mathrm{~mm}$ 未満の動脈瘤 の 5 年累積破裂率は $0 \%$ で，SAH 歴がある場合も $1.5 \%$ / 5 年（年間破裂率 $\fallingdotseq 0.3 \% /$ 年）にとどまった。 7 $12 \mathrm{~mm}$ の群でも $2.6 \% / 5$ 年 (年間破裂率 $\fallingdotseq 0.5 \% /$ 年, SAH 歴の 区別なし）と低值であった。一方，IC-PC を含む後方循 環動脈瘤の破裂率は, $7 \mathrm{~mm}$ 未満で $2.5 \% / 5$ 年 $(\mathrm{SAH}$ 歴 なし）および $3.4 \%$ (SAH 歴あり), 7〜 $12 \mathrm{~mm}$ で 14.5\%/ 5 年（SAH 歴の区別なし）であり, 前方循環より高い值 を示した。多変量解析では(1)瘤の大きさ $(\geqq 7 \mathrm{~mm})$, (2) 部位（IC-PC と脳底動脈先端部瘤）が有意な危険因子で あった。過去の SAH 歴は $7 \mathrm{~mm}$ 未満の瘤においてのみ破 裂に関与していたが，それ以上の径では関連がなかっ た。本研究結果は, 現在も欧米における標準とされてい る.

\section{Ishibashi らによる単一施設研究（日本，2009 年) ${ }^{6)}$}

東京慈恵会医科大学における 419 患者 529 動脈瘤 （88\%が前方循環動脈瘤）の追跡研究である（以後 JIKEI と標記). 平均観察期間 2.5 年と短期ながら, $5 \mathrm{~mm}$ 未満 の小型病変が $0.8 \% /$ 年の率で破裂し, 特に $\mathrm{SAH}$ 歷がある 患者の破裂率は $4.5 \%$ / 年に達した。また $10 \mathrm{~mm}$ を超える
動脈瘤の破裂率は $7.1 \%$ / 年, $25 \mathrm{~mm}$ 超では $43.1 \%$ / 年と 高率であった。

\section{SUAVe Study（日本, 2010 年) ${ }^{12)}$}

国立病院機構 12 施設の多施設共同研究である SUAVe (Small Unruptured Aneurysm Verification) Study は, $5 \mathrm{~mm}$ 未満の小型瘤を登録し，治療せずに経過観察した前方視 的研究である. 374 患者 448 動脈瘤を平均 3.5 年間観察し たところ，破裂は 7 例（1.9\%）に生じ，破裂率は $0.54 \%$ / 年（単発 $0.34 \% /$ 年，多発 $0.95 \% /$ 年）と算出された。こ れは ISUIA II における 7 12 $\mathrm{mm} の$ 前方循環動脈溜の年 間破裂率と同等である。破裂した 7 例中 4 例 $(57 \%)$ は, 観察期間中サイズが不変であったにもかかわらず，破裂 時には増大していた。多変量解析では, (1)50 歳未満, (2) $4 \mathrm{~mm}$ 以上, (3)高血圧, (4)多発性動脈瘤が破裂の独立危 険因子とされたが，過去の SAH 歴は影響していなかっ た。また破裂例とは別に，瘤形態が変化 $(2 \mathrm{~mm}$ 以上の 増大または bleb 新生）したため, 10 例が治療された。

\section{UCAS Japan（日本, 2012 年 $)^{14)}$}

日本未破裂脳動脈瘤悉皆調査. UCAS Japan (Unruptured Cerebral Aneurysm Study of Japan，2012 年）は，2001 年 1 月〜 2004 年 4 月に登録された $3 \mathrm{~mm}$ 以上の未破裂脳動 脈瘤 6,697 個に対する前方視的観察研究である. 治療介 入は任意であり, 受診から中央值 48 日で 3,050 個が治療 された(治療までの期間は解析に含める)。治療待機中ま たは経過観察中に 111 個が破裂し，破裂率は $0.95 \% /$ 年で あった。

動脈瘤の部位・瘤径別の年間破裂率が詳細に示された (Table 2)，多変量解析により，(1)瘤径 $\geqq 7 \mathrm{~mm}$, (2)前交通 
Table 2 Annual rupture rate proposed in the UCAS Japan ${ }^{14)}(\% /$ year $)$

\begin{tabular}{l|c|c|c|c|c|c}
\hline & Number & $3-4 \mathrm{~mm}$ & $5-6 \mathrm{~mm}$ & $7-9 \mathrm{~mm}$ & $10-24 \mathrm{~mm}$ & $\geqq 25 \mathrm{~mm}$ \\
\hline MCA & 2,425 & 0.23 & 0.31 & 1.56 & 4.11 & 16.87 \\
ACoA & 1,037 & 0.90 & 0.75 & 1.97 & 5.24 & 39.77 \\
ICA & 1,245 & 0.14 & 0 & 1.19 & 1.07 & 10.61 \\
IC-PC & 1,037 & 0.41 & 1.00 & 3.19 & 6.12 & 126.97 \\
BA $^{\dagger}$ & 445 & 0.23 & 0.46 & 0.97 & 6.94 & 117.82 \\
VA $^{*}$ & 123 & 0 & 0 & 0 & 3.49 & 0 \\
Other & 385 & 0.78 & 1.37 & 0 & 2.81 & 0 \\
\hline Total & 6,697 & 0.36 & 0.50 & 1.69 & 4.37 & 33.40 \\
\hline
\end{tabular}

${ }^{\dagger}$ Basilar tip and BA-SCA, ${ }^{\star}$ VA-PICA and vertebra-basilar junction

動脈（anterior communicating artery：ACoA）および IC$\mathrm{PC}$ 分岐部，(3)daughter sac（bleb），の 3 つが破裂の独立 危険因子とされた。高歯（ $\geqq 70$ 歳）, 高血圧症, 脳底動 脈瘤は単変量解析で有意であったが，多変量解析では有 意水準に達しなかった。過去の SAH 歴(登録例の 4\%), $\mathrm{SAH}$ 家族歴，多発性脳動脈瘢は，破裂との関連がみられ なかった.

本研究は，日本人コホートにおける脳動脈瘤破裂率を 部位別・サイズ別に詳細に示した点, ACoA と IC-PCの 高いリスクを示した点, 前方視的研究で初めて daughter sacのリスクを証明した点により, 国内外に大きなイン パクトを与えた. 本研究の limitation は, 日本人コホート であり欧米人にそのまま適応しづらいことである。ただ これは，日本人がISUIA II を参照する場合も同じである。 また「観察期間中にハイリスク病変が任意に治療されて いく」という回避しがたいバイアスが存在する（その意 味で全員観察の SUAVe は貴重である)。現にUCAS で経 過中に治療された瘤は，非治療の瘤と比べて有意に大き く, daughter sac 保有率が高かった。論文では，これら の選択バイアスにより「全体の破裂率は過小評価されて いる」と指摘されている。

\section{Juvela らによる長期観察研究 (フィンランド, 2013 年 ${ }^{7)}$}

1967 年まで同国唯一の脳神経外科施設であり，1976 年まで同国人口の $88 \%$ をカバーしたへルシンキ大学中 央病院における長期観察研究である.未破裂脳動脈瘤に 対して治療介入が行われなかった 1956〜1978 年に診断 された 142 人 181 動脈箇 (平均瘤径 $5.1 \mathrm{~mm}, 92 \%$ が過去 のSAH に関連して発見)が, 平均 21.6 年間観察された。 これは $80 \%$ の患者で診断後の全人生追跡となった。観察 期間中の破裂イベントは 34 例（24\%）に生じ, 全体の破 裂率は $1.1 \% /$ 年, 累積破裂率は 10 年 $10.5 \%, 20$ 年 $23 \%$,
30 年 $30.1 \%$ であった。年齢階層が若いほど破裂率が高 かった。診断時 50 歳以下の若年患者（111人）では 25 年間ほぼ同じペースで破裂したが, 25 年以後はイベント がなかった。一方, 51 歳以上（31 人）では, 破裂は最初 の 10 年間のみであった。瘤径別の解析では, 3〜6 mm の 小型病変であっても 25 年間にわたり同じペースで破裂 した。(1)若年，(2)瘤径 $\geqq 7 \mathrm{~mm}$ ，(3) $\mathrm{ACoA}$ 動脈瘤，(4)哭煙 が破裂の独立危険因子であった。本論文の結論は，(1)50 歳未満の患者ではサイズにかかわらず治療を考慮すべ き，(2)高齢者の小型（<7 mm）瘤の治療適応については 疑問あり，(3禁煙がきわめて大切，の 3 点である.

なお, 多変量解析で年齢を独立危険因子とした前方視 的研究は本研究とSUAVeのみであり, いずれも若年を高 リスクとしている，反対に，いずれも単変量解析ながら UCAS Japan では 70 歳以上, 後述の Wermer らのメタア ナリシス $(2007 \text { 年 })^{17)}$ では 60 歳以上の高齢が有意な危険 因子とされ，患者年齢と破裂リスクに関しては結果の相 違がみられる。

\section{6 前方視的研究で示された破裂危険因子}

動脈瘤サイズという共通の危険因子を除けば，前述の 年齢をはじめ, 各研究で示された結果はさまざまであ る。また「検討したが否定された」のか,「検討されてい ない」のかで意味が異なり, 誤解や混乱を生じやすい. $5 つ$ 前方視的研究で示された破裂危険因子を Table 3 に まとめた。多発性動脈瘤や過去のSAH歴で相違がみられ る. SAH の家族歴は，臨床現場では心情的に重視されや すいが，検討された 3 研究のいずれにおいてもが証明さ れていない.

\section{7 前方視的研究の統合解析とメタアナリシス}

1. Hishikawa らによる高齢患者の解析 $(2015 \text { 年 })^{3)}$

JIKEI, UCAS および未破裂動脈瘤治療合併症に関する 
Table 3 Proposed risk factors of aneurysmal rupture in 5 prospective studies

\begin{tabular}{|c|c|c|c|c|c|}
\hline & ISUIA II & JIKEI & SUAVe & UCAS & Juvela \\
\hline Age & NO & $(-)$ & YES $(<50 \mathrm{y})$ & UA $(\geqq 70 y)$ & YES $(\leqq 50 \mathrm{y})$ \\
\hline Size & YES & YES & YES & YES & YES \\
\hline Location & YES & YES & NO & YES & YES \\
\hline Shape (bleb) & $\begin{array}{c}\text { (BA tip, IC-PC) } \\
(-)\end{array}$ & $\begin{array}{c}\text { (posterior) } \\
(-)\end{array}$ & $(-)$ & $\begin{array}{c}(\mathrm{ACoA}, \mathrm{IC}-\mathrm{PC}) \\
\text { YES }\end{array}$ & $\begin{array}{c}(\mathrm{ACoA}) \\
(-)\end{array}$ \\
\hline Multiplicity & $(-)$ & NO & YES & NO & NO \\
\hline History of SAH & $\begin{array}{c}\text { YES } \\
(<7 \mathrm{~mm} \text { only })\end{array}$ & YES & NO & NO & $(-)$ \\
\hline Family history of SAH & $(-)$ & $(-)$ & NO & NO & NO \\
\hline Hypertension & $(-)$ & $(-)$ & YES & UA & Nearly YES \\
\hline Smoking & $(-)$ & $(-)$ & $(-)$ & $(-)$ & YES \\
\hline
\end{tabular}

YES : proved positive, UA : significant only in univariate analysis but not significant in multivariate analysis, NO : proved negative, $(-):$ not analyzed

前方視的研究である UCAS II ${ }^{10)}$ の登録デー夕から, 70 歳 以上の 1,896 人 2,227 動脈瘤を抽出した統合解析 (pooled analysis) である。平均年齢は 74.3 歳であり, $10.9 \%$ が 80 歳以上であった。平均 2.2 年の観察期間中に 68 人 $(3.8 \%)$ に破裂イベントが生じ，破裂率は $1.6 \% /$ 年と算出され た。多変量解析では, (1) 80 歳以上 (ハザード比 2.02), (2)瘤径 $\geqq 7 \mathrm{~mm}$, (3)IC-PC 動脈瘤の 3 つが破裂の独立危険 因子であった。上記以外にも女性, 多発動脈瘤, 脳底動 脈瘤が単変量解析で有意であったが，多変量解析で有意 水準に達しなかった。観察期間中に 70〜 79 歳の患者の

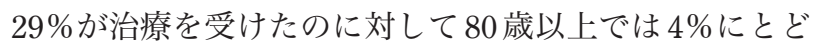
まり，こ机が選択バイアスとなったことを否定できない ものの, 本研究では超高齢者 ( $\geqq 80$ 歳) の高い破裂率が 示された.

\section{Wermer らによるメタアナリシス ${ }^{17)}$}

2007 年, Wermer（オランダ）らは，1998 年の Rinkel

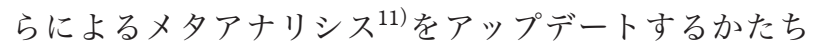
で，1955 2006 年の前方視的・後方視的 19 研究を解析 した。これは ISUIA I およびII を含むが，2007 年以降の JIKEI, SUAVe, UCAS を含んでいない. 内訳は(1)日本 10 研究 1,119 例, (2)フィンランド 1 研究 142 例, (3)北米お よびフィンランド以外の欧州 8 研究 3,436 例である（平 均観察期間 5.6 年).

破裂率は $1.2 \% /$ 年（観察期間が 5 年未満の研究）, $0.6 \% /$ 年 (同， $5 \sim 10$ 年), $1.3 \% /$ 年（同 10 年超）であっ た。単変量解析ではあるが, (1)高齢 ( $\geqq 60$ 歳), (2)女性, (3)日本またはフィンランド人, (4)瘤径 $\geqq 5 \mathrm{~mm}$, (5)後方循 環, (6)症候性病変が有意な危険因子とされた。本研究に より, 人種による未破裂脳動脈瘤の破裂率の差が明確に 示された。

\section{破裂リスクと治療適応決定に 関するスコアリング}

以上の前方視的研究の結果をもとに，2014 年以降，3 つのスコアリングシステムが提唱されている（Fig. 1 下 段左).

\section{PHASES Score $(2014)^{2)}$}

前項 1 〜 5の前方視的研究に, オランダの短期前方視 的コホート 93 例 ${ }^{16)}$ を加えたデー夕の統合解析に基づく, 破裂リスクのスコア化研究である。多変量解析で，(1)人 種（Population：日本人またはフィンランド人)，(2)高血

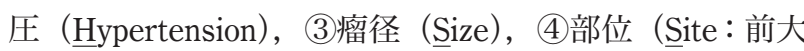
脳動脈・後交通動脈・後方循環系), の 4 つが破裂の独立 危険因子とされた。上記に加えて(5)年齢（Age：70 歳以 上）と（6過去の SAH 歴（Earlier SAH）を加えた 6 項目 (頭文字をとって PHASES) をスコア化した (Table 4A). 論文には合計スコアに応じた 5 年間破裂率が提示され， たとえば $3 ， 6 ， 9 ， 11$ 点でおのおの $0.7 \% / 5$ 年， $1.7 \% / 5$ 年, $4.3 \% / 5$ 年, $7.2 \% / 5$ 年である. 最高 22 点であるが, 12 点以上の破裂率は一括され $17.8 \% / 5$ 年となっている.

\section{UCAS Score (2015) $)^{13)}$}

UCAS Japan における多変量解析での独立危険因子 (1) サイズ, (2)部位, (3)daughter sac) に, 単変量解析で八 ザード比の高かった(4)年齢（ $\geqq 70$ 歳)，(5)女性，(6)高血 圧を加えた 6 項目をスコア化した (Table 4B). 合計スコ アに応じた 3 年間破裂率が提示され，たとえば $0,2,4$, 6,8 点でおのおの $0.2 \% / 3$ 年, $0.6 \% / 3$ 年, $1.4 \% / 3$ 年, $3.7 \% / 3$ 年, $7.6 \% / 3$ 年である. 最高 15 点であるが, 9 点 
Table 4 PHASES Score $^{2)}$ and UCAS score ${ }^{13)}$

\begin{tabular}{l|l|c} 
A PHASES Score & \\
\hline Population & North American and European & 0 \\
& Japanese & 3 \\
& Finnish & 5 \\
\hline Hypertension & No & 0 \\
& Yes & 1 \\
\hline Age (year) & $<70$ & 0 \\
& $\geqq 70$ & 1 \\
\hline Size (mm) & $<7.0$ & 0 \\
& $7.0-9.9$ & 3 \\
& $10-19.9$ & 6 \\
& $\geqq 20$ & 10 \\
\hline Earlier SAH & No & 0 \\
& Yes & 1 \\
\hline Site & ICA & 0 \\
& MCA & 2 \\
& ACA/Pcom/posterior & 4 \\
\hline \multicolumn{2}{l}{ TOTAL $(0 \sim 22)$} & \\
\hline
\end{tabular}

\begin{tabular}{l|l|l}
\multicolumn{2}{l}{ B UCAS Score } & 0 \\
\hline Age (year) & $<70$ & 1 \\
\hline Sex & $\geqq 70$ & 0 \\
& Male & 1 \\
\hline \multirow{2}{*}{ Hypertension } & Female & 0 \\
& No & 1 \\
\hline Size (mm) & Yes $\leqq$ size $<7$ & 0 \\
& $7 \leqq$ size $<10$ & 2 \\
& $10 \leqq$ size $<20$ & 5 \\
& $20 \leqq$ & 8 \\
\hline Location & ICA & 0 \\
& ACA, VA & 1 \\
& MCA, BA & 2 \\
& ACoA, IC-PC & 3 \\
\hline Daughter sac & No & 0 \\
& Yes & 1 \\
\hline \multicolumn{2}{c}{ TOTAL $(0 \sim 15)$} & \\
\hline
\end{tabular}

Table 5 Details of the 2 groups (ICA and other) in the UCAS Japan ${ }^{15)}$

\begin{tabular}{ll|c|c|c}
\hline & Number & Rupture & $\begin{array}{c}\text { Rupture } \\
\text { rate } \\
(\% / y)\end{array}$ \\
\hline ICA $\quad$ IC-paraclinoid & 785 & 4 & 0.26 \\
& IC dorsal & 41 & 0 & - \\
IC bifurcation & 154 & 2 & 0.79 \\
IC-ACho & 228 & 1 & 0.30 \\
Other & ACA A1 & 92 & 1 & 0.64 \\
ACA A2 & 203 & 1 & 0.31 \\
Other supratentorial & 49 & 2 & 2.07 \\
Other infratentorial & 41 & 2 & 2.61 \\
\hline
\end{tabular}

行うかどうかの「判断のためのスコア」を開発した。患 者因子 (年齢や既往, 合併症など), 動脈瘤因子 (サイ ズ, 部位など), 治療関連因子（合併症の出やすさ）の計 29 項目をスコア化し, (1)治療推奨スコアと(2)経過観察推 奨スコアを別々に算出する． 3 点以上の差でスコアの高 い方針が推奨され，2 点以下の場合は他の要素も勘案し て決定する。

\section{臨床現場への適用と問題点}

現在，国内の臨床現場では UCAS Japan の破裂率デー 夕が頻用されるが，下記の注意すべき問題点がある.

\section{ICA 瘤 0\%問題}

IC-PC 以外の硬膜内内頝動脈（internal carotid artery：

本論文では UCAS Score と PHASES Score を, データ 引用のない無関係の前方視的研究に当てはめて検証した (external validation). UCAS Score を UCAS Japan 以外の 日本の 3 研究 (JIKEI, SUAVe, UCAS II ) のデータ (1,161 例）に当てはめると，実際の破裂率を正確に予測した。 一方, PHASES score は主要な前方視的 5 研究をすべて 引用しているため検証の場はUCAS II しかない. 両 score をこれに当てはめると, PHASES score は破裂率を過小 評価する傾向にあった。

3 UIA (unruptured intracranial aneurysm) Treatment Score ${ }^{1)}$

過去の自然歴研究と治療合併症研究をもとに, 治療を

ICA）瘤には内頝動脈傍鞍部（IC paraclinoid）, 前脈絡叢 動脈分岐部 (internal carotid-anterior choroidal artery：ICACho), 内頝動脈終末部 (IC bifurcation) が含まれるが, 5 6 $\mathrm{mm}$ 病変の破裂率が 0\%/年とされ（Table 2)，リス ク評価や患者説明時に困惑する. 疾患頻度に比べ $\mathrm{SAH}$ 症 例が少ないと実感できる IC paraclinoid は別にしても，6 $\mathrm{mm}$ 台後半の不整形 IC-ACho 動脈留をゼロリスクといい 切る脳神経外科医はいないであろう。

UCAS 論文には WEB 上で参照，ダウンロード可能な supplementary appendix があり ${ }^{15)}$, 登録病変の詳細が掲 載されている (Table 5 : 一部抜粋)。 IC-PC 以外の ICA は 全体の $18.6 \%$ で，中大脳動脈瘤に次ぐ大集団であるが, 
その $63 \%$ IC paraclinoid が占めている. ICA瘤の破裂は 7 例（全破裂例の $6.3 \%$ ）と少なく，いずれも $5 \sim 6 \mathrm{~mm}$ の 階級外で生じたと推定される。 また IC-ACho は全体の 3.4\%（228 例）に過ぎず，破裂は 1 例のみであるため単 独で階級別破裂率を解析できない. ICA，特に IC-ACho や IC bifuracation の 0\%問題に対しては，上記の事情を理 解したうえで，慎重に説明を行うことが求められる。

Table 2 のデータのみではなく, UCAS Score（Table 4)の 使用も選択肢となる。 UCAS Score は 9 点以上の破裂率は 一括に $17 \% / 3 \mathrm{y}$ とされるため, 大型病変では破裂率が容 易に飽和してしまう欠点があるが， $7 \mathrm{~mm}$ 未満であ机ば そのような事態は生じない.

\section{2「Other」とは何か?}

UCAS で「other」にまとめられた集団（385 例）の内 訳を知っておくべきである (Table 5). Supplementary appendix によれば, (1)前大脳動脈 (anterior cerebral artery：ACA）A2 部動脈瘤（distal ACA）が 203 例（53\%） と過半数を占める. 次点は(2)ACA A1 動脈溜（92 例）で あり, 以下(3)その他のテント上病変 49 例（おそらく後大 脳動脈瘤など), (4)その他のテント下病変 41 例（おそら く脳底動脈-前下小脳動脈分岐部動脈瘤や後下小脳動脈 遠位部動脈瘤など）の順になっている。「Other」のカテ ゴリーは 3〜 $4 \mathrm{~mm}, 5 \sim 6 \mathrm{~mm}$ の破裂率が 0.78\%/年, $1.37 \%$ /年と高く, IC-PC や ACoA を上回る。しかし ACA 病変の破裂率が高いわけではなく（Table 5)，「other」の 代表のようにリスク説明をするのは正しくない，実際に 破裂率を押し上げているのは(3)および(4)と考えられる.

\section{おわりに}

未破裂脳動脈瘤の自然歴に関する研究の歴史を解説し た。近年の研究はメタアナリシスや, pooled analysis, リ スクスコアリングなどデータ引用が頻繁に行われてお り, 結果の理解には基礎デー夕の出所, 流れの把握が必 須である。また，おのおのの前方視的研究で，リスク因 子として何が証明され，何が否定されたのかを正しく理 解することも大切である。本稿のために作成した系統樹 （Fig. 1）とリスク因子一覧（Table 3）が，理解と記憶の 一助とな扎ば幸いである。系統樹右側に位置する治療り スク研究については，本稿で触れることができなかった が，予防的治療の可否は自然歴と治療りスクの比較によ り判断されるべきものであり, 自然歴同様にきわめて重 要である.

最後に，これまで未破裂脳動脈瘤研究に尽力された多
くの先生方に心から敬意を表する。この系統樹をみれ ば，この分野における日本の脳神経外科医の多大なる貢 献が一目瞭然である.

\section{COIについて}

本論文の全著者において，本論文に関して開示すべき COI はありません。 また著者は全員, 日本脳神経外科学会への平 成 28 年 1 月〜 12 月に打りる COI 自己申告書オンライン登録 を完了しています.

\section{文 献}

1) Etminan N, Brown RD Jr, Beseoglu K, Juvela S, Raymond J, Morita A, Torner JC, Derdeyn CP, Raabe A, Mocco J, Korja M, Abdulazim A, Amin-Hanjani S, Al-Shahi Salman R, Barrow DL, Bederson J, Bonafe A, Dumont AS, Fiorella DJ, Gruber A, Hankey GJ, Hasan DM, Hoh BL, Jabbour P, Kasuya H, Kelly ME, Kirkpatrick PJ, Knuckey N, Koivisto T, Krings T, Lawton MT, Marotta TR, Mayer SA, Mee E, Pereira VM, Molyneux A, Morgan MK, Mori K, Murayama Y, Nagahiro S, Nakayama N, Niemelä M, Ogilvy CS, Pierot L, Rabinstein AA, Roos YB, Rinne J, Rosenwasser RH, Ronkainen A, Schaller K, Seifert V, Solomon RA, Spears J, Steiger HJ, Vergouwen MD, Wanke I, Wermer MJ, Wong GK, Wong JH, Zipfel GJ, Connolly ES Jr, Steinmetz H, Lanzino G, Pasqualin A, Rüfenacht D, Vajkoczy P, McDougall C, Hänggi D, LeRoux P, Rinkel GJ, Macdonald RL : The unruptured intracranial aneurysm treatment score: a multidisciplinary consensus. Neurology $\quad \mathbf{8 5}: 881-889,2015$.

2) Greving JP, Wermer MJ, Brown RD Jr, Morita A, Juvela S, Yonekura M, Ishibashi T, Torner JC, Nakayama T, Rinkel GJ, Algra A: Development of the PHASES score for prediction of risk of rupture of intracranial aneurysms : a pooled analysis of six prospective cohort studies. Lancet Neurol 13: 59-66, 2014.

3) Hishikawa T, Date I, Tokunaga K, Tominari S, Nozaki K, Shiokawa Y, Houkin K, Murayama Y, Ishibashi T, Takao H, Kimura T, Nakayama T, Morita A; For UCAS Japan and UCAS II Investigators : Risk of rupture of unruptured cerebral aneurysms in elderly patients. Neurology $85: 1879-$ $1885,2015$.

4) International Study of Unruptured Intracranial Aneurysms Investigators : Unruptured intracranial aneurysms-risk of rupture and risks of surgical intervention. $N$ Engl J Med 339: 1725-1733, 1998.

5) Wiebers DO, Whisnant JP, Huston J 3rd, Meissner I, Brown RD Jr, Piepgras DG, Forbes GS, Thielen K, Nichols D, O' Fallon WM, Peacock J, Jaeger L, Kassell NF, KongableBeckman GL, Torner JC ; International Study of Unruptured Intracranial Aneurysms Investigators : Unruptured intracranial aneurysms : natural history, clinical outcome, and risks of surgical and endovascular treatment. Lancet $362: 103^{-}$ 110, 2003.

6) Ishibashi T, Murayama Y, Urashima M, Saguchi T, Ebara M, Arakawa H, Irie K, Takao H, Abe T: Unruptured intracranial aneurysms : incidence of rupture and risk factors. Stroke 40:313-316, 2009.

7) Juvela S, Poussa K, Lehto H, Porras M ; Natural history of unruptured intracranial aneurysms : a long-term follow-up study. Stroke $\quad 44: 2414-2421,2013$. 
8) Locksley HB : Natural history of subarachnoid hemorrhage, intracranial aneurysms and arteriovenous malformations. $J$ Neurosurg 25:321-368, 1966.

9) Morita A, Fujiwara S, Hashi K, Ohtsu H, Kirino T : Risk of rupture associated with intact cerebral aneurysms in the Japanese population: a systematic review of the literature from Japan.J Neurosurg 102: 601-606, 2005.

10）森田明夫，UCAS II 研究者グループ：UCAS II における未 破裂脳動脈瘤治療成績：中間報告一日本における未破裂 脳動脈瘤治療の現況とスタンダードの追究一。脳外誌 20:484-490, 2011.

11) Rinkel GJE, Djibuti M, Algra A, van Gijn J : Prevalence and risk of rupture of intracranial aneurysms : a systematic review. Stroke 29:251-256, 1998.

12) Sonobe M, Yamazaki T, Yonekura M, Kikuchi H : Small unruptured intracranial aneurysm verification study: SUAVe study, Japan. Stroke 41: 1969-1977, 2010.

13) Tominari S, Morita A, Ishibashi T, Yamazaki T, Takao H, Murayama Y, Sonobe M, Yonekura M, Saito N, Shiokawa Y, Date I, Tominaga T, Nozaki K, Houkin K, Miyamoto S, Kirino T, Hashi K, Nakayama T ; Unruptured Cerebral Aneurysm Study Japan Investigators : Prediction model for $3-$ year rupture risk of unruptured cerebral aneurysms in
Japanese patients. Ann Neurol $77:$ 1050-1059, 2015.

14) UCAS Japan Investigators, Morita A, Kirino T, Hashi K, Aoki N, Fukuhara S, Hashimoto N, Nakayama T, Sakai M, Teramoto A, Tominari S, Yoshimoto $\mathrm{T}$ : The natural course of unruptured cerebral aneurysms in a Japanese cohort. $N$ Engl JMed 366:2474-2482, 2012.

15) UCAS supplementary Appendix. N Engl J Med 2012. http:// www.nejm.org/doi/suppl/10.1056/NEJMoa1113260/ suppl_file/nejmoa1113260_appendix.pdf

16) Wermer MJ, van der Schaaf I, Velthuis BK, Majoie CB, Albrecht KW, Rinkel GJ : Yield of short-term follow-up CT/ MR angiography for small aneurysms detected at screening. Stroke 37: 414-418, 2006.

17) Wermer MJ, van der Schaaf IC, Algra A, Rinkel GJ : Risk of rupture of unruptured intracranial aneurysms in relation to patient and aneurysm characteristics : an updated metaanalysis. Stroke 38: 1404-1410, 2007.

18) Wiebers DO, Whisnant JP, Sundt TM Jr, O'Fallon WM : The significance of unruptured intracranial saccular aneurysms. $J$ Neurosurg 66:23-29, 1987.

19) Yasui N, Suzuki A, Nishimura H, Suzuki K, Abe T : Longterm follow-up study of unruptured intracranial aneurysms. Neurosurgery 40 : 1155-1159, 1997.

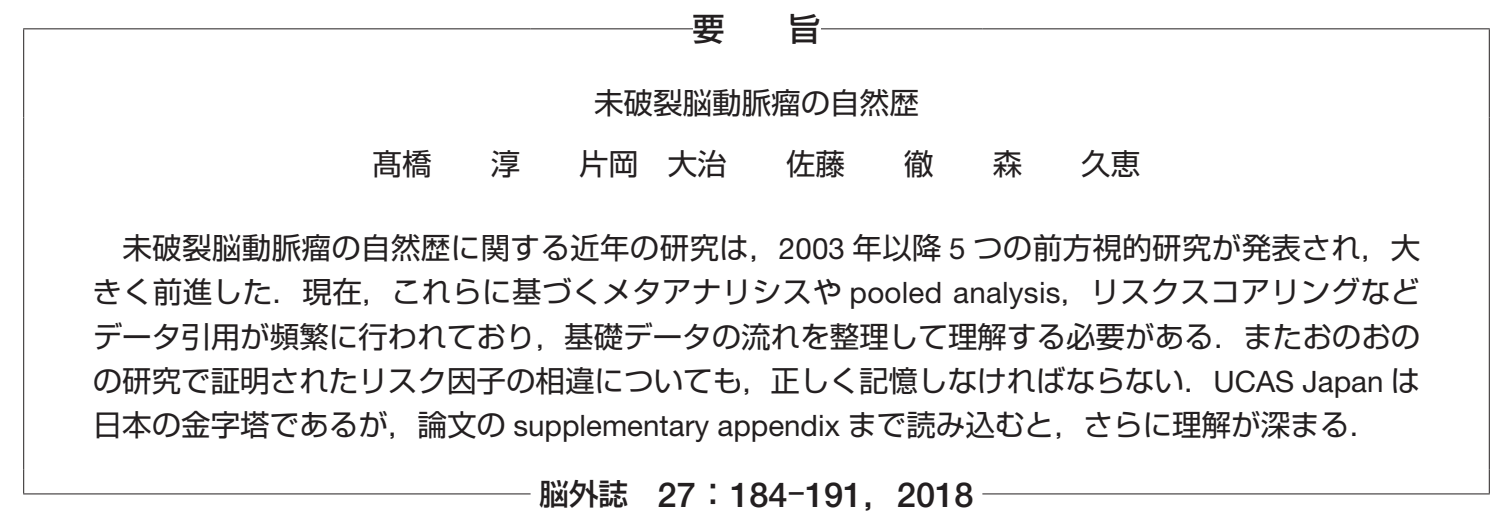

